\title{
CERTAIN SUBCLASSES OF MULTIVALENT PRESTARLIKE FUNCTIONS WITH NEGATIVE COEFFICIENTS
}

\author{
M. K. AOUF
}

Abstract. The object of the present paper is to investigate coefficient estimates for functions belonging to the subclasses $R_{\gamma}^{p}[\alpha, \beta]$ and $C_{\gamma}^{p}[\alpha, \beta]$ of p-valent $\gamma$-prestarlike functions of order $\alpha$ and type $\beta$ with negative coefficients. We obtain extreme points, distortion theorems, integral operators and radii of starlikeness and convexity for functions belonging to the classes $R_{\gamma}^{p}[\alpha, \beta]$ and $C_{\gamma}^{p}[\alpha, \beta]$. We also obtain several results for the modified Hadamard products of functions belonging to the classes $R_{\gamma}^{p}[\alpha, \beta]$ and $C_{\gamma}^{p}[\alpha, \beta]$.

Mathematics subject classification (2000): 30C45.

Key words and phrases: p-Valent, prestarlike functions, extreme points, modified Hadamard products.

\section{REFERENCES}

[1] O. P. Ahuja AND H. Silverman, Convolutions of prestarlike functions, Internat. J. Math. Math. Sci. 6 (1983), no. 1, 59-68.

[2] K. Aouf, A generalization of multivalent functions with negative coefficients, J. Korean Math. Soc. 25 (1988), no. 1, 53-66.

[3] M. K. Aouf, H. M. Hossen And H. M. SRIVASTava, Certain subclasses of prestarlike functions with negative coefficients, Kumamoto J. Math. 11 (1998), 1-17.

[4] M. K. AOUF AND G. S. SALAGEAN, Certain subclasses of prestarlike functions with negative coeffcients, Studia Univ. Babes - Bolyia Math. 39 (1994), no. 1, 19-30.

[5] M. K. AOUf AND H. Silverman, Subclasses of p-valent and prestarlike functions, Internat. J. Contemp. Math. Sci. 2 (2007), no. 8, 357-372.

[6] M.-P. CHEN, Multivalent functions with negative coefficients in the unit disc, Tamkang J. Math. 17 (1986), no. 3, 127-137.

[7] H. M. Hossen, Quasi-Hadamard product of certain p-valent functions, Demonstratio Math. 33 (2000), no. 2, 277-281.

[8] G. A. Kumar and Gl. Reddy, Certain class of prestarlike functions, J. Math. Res. Exposition 12 (1992), no. 3, 407-412.

[9] S. OwA, On certain classes of p-valent functions with negative coefficients, Simon Stevin, 59 (1985), 385-402.

[10] S. Owa AND B. A. URALEGadd, A class of functions $\alpha$ - prestarlike of order $\beta$, Bull. Korean Math. Soc. 21(1984), no. 2, 77-85.

[11] D. A. Patil AND N. K. ThaKare, On convex hulls and extreme points of p-valent starlike and convex classes with applications, Bull. Math. Soc. Sci. Math. R.S. Roumanie (N.S.), 27 (1983), no. 75, 145-160.

[12] R. K. RAINA AND H. M. SRIVASTAVA, A unified presentation of certain subclasses of prestarlike functions with negative coefficients, Comput. Math. Appl. 38 (1999), 71-78.

[13] A. SCHILD AND H. SILVERMAN, Convolution of univalent functions with negative coefficients, Ann. Univ. Mariae Curie - Sklodowska Sect. A, 29 (1975), 99-106.

[14] G. M. Shenen, T. Q. SAlim AND M. S. MAROUF, A certain class of multivalent prestarlike functions involving the Srivastava -Saigo - Owa fractional integral operator, Kyungpook Math. J. 44 (2004), $353-362$. 
[15] H. Silverman AND E. M. SiLvia, Subclasses prestarlike functions, Math. Japon. 29(1984), 929-935.

[16] H. M. SRIVASTAVA AND M. K. AOUF, Some applications of fractional calculus operators to certain subclasse of prestarlike functions with negative coefficients, Comput. Math. Appl. 30 (1995), no. 1, 53-61.

[17] B. A. URALEgADDI AND S. M. SARANGI, Certain generalization of prestarlike functions with negative coefficients, Ganita 34 (1983), 99-105. 